PRZEGLĄD NAUK HISTORYCZNYCH 2016, R. XV, NR 2

http://dx.doi.org/10.18778/1644-857X.15.02.03

Piotr TAFIlowski

UniWERSYTET WARSZAWSKI ${ }^{*}$

\title{
Pojedynki władców: zagadnienie komunikacji rytualnej
}

Streszczenie. W tekście podjęto próbę wyjaśnienia znaczenia zjawiska, jakim były pojedynki władców. Wydaje się, że najlepiej zrozumieć je można, umieszczając je w kontekście komunikacji rytualnej. Wezwania do pojedynków władców, choć faktycznie nigdy żaden się nie odbył, były gestami rozpowszechnionymi od starożytności aż do czasów nowożytnych. Znamy je $z$ licznych źródeł dokumentowych, literackich (Iliada) oraz ikonograficznych, a także z kronik. Wydaje się jednak, że dotychczas historycy nie poświęcili im należytej uwagi i nie zdołali tego zagadnienia prawidłowo odczytać oraz należycie wyjaśnić. Próba nowego spojrzenia na tę tematykę podjęta została w prezentowanym artykule.

Słowa kluczowe: pojedynek, władcy, komunikacja rytualna.

$\mathrm{N}$ ie ma władzy, która nie posługiwałaby się komunikacją rytualna" - pisze Gerd Althoff w znakomitej Potedze rytuału ${ }^{1}$. Tej właśnie problematyce, jednemu z zagadnień komunikacji rytualnej, chcę poświęcić ten tekst. Umieszczając moje obserwacje w tym kontekście i przyjmujac książkę niemieckiego mediewisty za punkt wyjścia, wykraczam jednak dość daleko, zarówno chronologicznie, jak i przedmiotowo, poza obszar jego zainteresowań. Gerd Althoff twierdzi, że o komunikacji rytualnej można mówić dopiero w czasach karolińskich, choć pewne jej przejawy daja się zaobserwować już w czasach merowińskich. Skupił się on jednak na rytuałach w programie sprawowania władzy i w porzacdku feudalnym,

*Wydział Dziennikarstwa, Informacji i Bibliologii, Katedra Informatologii.

${ }^{1}$ G. Althoff, Potega rytuału: symbolika władzy $w$ średniowieczu, Warszawa 2011 , s. 32. 
wpisujących się w program długofalowej władzy politycznej. Rytuały militarne pozostaja poza polem jego obserwacji. Ja natomiast przyjmuję, że pojedynki mające rozstrzygać losy całych ludów należą do komunikacji rytualnej, stanowiacej stały element w dziejach ludzkości od starożytności aż po wiek XXI, choć oczywiście na przestrzeni stuleci zmieniały się ich formy.

Zjawisko to daje się przynajmniej częściowo opisać jedną z definicji podawanych przez Althoffa: „tzw. rytuały polityki sa rozumiane jako akty performance, które jednak nie sa bezrefleksyjne, lecz precyzyjnie zaplanowane i wprowadzane przez reżysera na scenę w celu stworzenia jakiegoś konkretnego wizerunku lub puszczenia

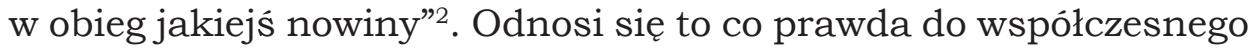
rozumienia polityki, nie zmienia to jednak faktu, że stanowi także część zjawisk historycznych, na tyle złożonych, że niedających się zamknąc w jednej definicji. Do współczesności przyjdzie jeszcze powrócić na zakończenie tekstu.

Amerykański komunikolog Eric W. Rothenbuhler poświęcił komunikacji rytualnej specjalne opracowanie. Zaproponował w nim taką definicję tego zjawiska: „uczestnicy rytuału wykonują coś symbolicznie, posługują się symbolami w celu osiągnięcia celów społecznych [...]. Rytuał stanowi dobrowolne wykonanie odpowiednio uwzorowanego zachowania w celu symbolicznego oddziaływania na życie poważne lub uczestnictwa w nim"3. Również ona jest użyteczna dla moich celów i prawidłowo opisuje interesujące mnie zjawisko.

Polityką kieruje władca, który jest przede wszystkim symbolem. W tableau władzy nie jest istotna fizyczna osoba, która staje się jej nosicielem. Najważniejszą kwestia jest to, co ta osoba symbolizuje, jaki ładunek symboliczny ze soba niesie. Nie przed konkretnym mężczyzna klękaja poddani, ale przed idea Króla. Osoba stanowi tylko widzialne ucieleśnienie idei. Władza królewska jest sacrum, pochodzi od bogów.

Władca opromieniony jest świętościa ex officio. Godność, świętość, Drugie Ciało znajdują w nim nosiciela nie ze względu na jego indywidualne cnoty, zasługi jako śmiertelnego człowieka, ale ze względu na godność, jaka na niego spływa dzięki pochodzeniu z królewskiego rodu czy namaszczeniu.

${ }^{2}$ Ibidem, s. 13. Więcej na ten temat por. P. Bu c, Pułapki rytuału: między wczesnośredniowiecznymi tekstami a teoria nauk społecznych, Warszawa 2011.

${ }^{3}$ E.W. Rothenbuhler, Komunikacja rytualna: od rozmowy codziennej do ceremonii medialnej, Kraków 2003, s. 44-45. 
Możemy zatem mówić o dwóch inkarnacjach monarszych: ciele fizycznym (król) i ciele symbolicznym, mistycznym (Król). Jedno jest ułomne i śmiertelne, drugie zaś nie podlega zwykłym ograniczeniom fizycznym, nie zna śmierci, choroby, jest wieczne i nieomylne. Król żyje w dwóch wymiarach: doczesnym i nadprzyrodzonym. Wieczność Króla wiąże się z jego Ciałem niematerialnym i nieśmiertelnym; materialne i śmiertelne jest tylko ciało naturalne. Król zatem nie umiera nigdy, zapewniajac swojemu państwu ciagłość władzy4. We współczesnych państwach rola ta przeszła na prezydentów republik czy monarchów konstytucyjnych.

Pojedynek jest wreszcie walka orężna dwóch zawodników, którzy w ten sposób chca wykazać nie tylko swoją wyższość nad przeciwnikiem, lecz także (czy może przede wszystkim) udowodnić słuszność swej sprawy i przychylność okazywana przez siły wyższe, bogów, Opatrzność. Siła równa się sprawiedliwości. W tym zakresie duellum tożsame będzie z ordalium: „sądy boże służyły także do rozstrzygania kwestii prawnych, odwoływano się do nich w sprawach politycznych. W 1033 r. w sporze pomiędzy Lutykami i Sasami na życzenie obu stron Konrad II nakazał stoczenie pojedynku"5.

Połaczenie tych elementów - aktów komunikacyjnych, uświęconej osoby władcy oraz pojedynku $z$ zasada pars pro toto, której celem było uniknięcie rozlewu krwi i ofiar podczas bitwy - stanowi przedmiot mojego zainteresowania. Tekst poświęcony jest jednej koncepcji rozwiązywania konfliktów, nazwijmy je współczesna terminologią: międzynarodowych. Biorac pod uwage cytowane ustalenia G. Althoffa oraz E.W. Rothenbuhlera, nie może ulegać wattpliwości, że mamy tu do czynienia z komunikacja rytualna w ramach państwa rozumianego jako splot relacji symbolicznych.

Czytelnikowi należa się jeszcze pewne uściślenia metodologiczne. W prezentowanym tekście nie będę szerzej zajmował się takimi zjawiskami, jak rycerski ethos ${ }^{6}$, honor czy etyka, jakkolwiek bez ich znajomości trudno byłoby wytłumaczyć ewolucję fenomenu

${ }^{4}$ E.H. Kantorowicz, Dwa Ciała Króla: studium ze średniowiecznej teologii politycznej, Warszawa 2007; J.-P. Roux, Król: mity i symbole, Warszawa 1998; J. Le Goff, Święty Ludwik, Warszawa 2001, s. 30.

${ }^{5} \mathrm{~J}$. Szy m c zak, Pojedynki i harce, turnieje i gonitwy. Walki o życie, cześć, sławę i pieniądze w Polsce Piastów i Jagiellonów, Warszawa 2008, s. 18.

${ }^{6} \mathrm{C}$. T aylor, Chivalry and the Ideals of Knighthood in France during the Hundred Years War, Cambridge 2013; D.J.B. Trim, The Chivalric Ethos and the Development of Military Professionalism, Leiden 2008; L.S. Zakrzewski, Ethos rycerski w dawnej i współczesnej wojnie, Warszawa 2004. 
władców pojedynkujacych się w imieniu swych wojsk i poddanych. $\mathrm{W}$ pogańskiej starożytności i w świecie barbarzyńskim, podobnie jak we wczesnym chrześcijańskim średniowieczu, czyli tam, gdzie koncepcja teologii politycznej nie była jeszcze wykształcona, nie miało większego znaczenia, kto do pojedynku w imieniu całej armii stawał. Dopiero sformułowanie koncepcji opisanej przez Ernsta H. Kantorowicza, sakralizacja władzy politycznej sprawiła, że taki gest rytualny włączony został $\mathrm{w}$ theatrum władzy. Istnienia takiej korelacji dowodza podawane poniżej przykłady.

Nie wchodza w zakres moich zainteresowań turnieje rycerskie. Nie zamierzam również rozpatrywać zadań i obowiąków królewskich, jednakże trzeba wspomnieć, że jednym $z$ głównych było zapewnienie pokoju swym poddanym. Jest o tym stale mowa w źródłach historycznych: dawnej literaturze, zwierciadłach władców, podkreślaja ten aspekt teoretycy polityki. W praktyce było to zadanie niesłychanie trudne, jeśli nie wręcz niemożliwe do spełnienia. Jednym ze sposobów dążenia do tego ideału były omawiane tu pojedynki.

W tym artykule moge jedynie zasygnalizować problem, a nie dogłębnie go opisać, choć jestem przekonany, że pewna skrótowość nie osłabia jego tezy. Wydaje się, że ważne jest zwrócenie uwagi na opisane tu kwestie, sformułowanie pytania badawczego, a jednocześnie nadanie problematyce właściwego wymiaru przez ujęcie jej w kategoriach komunikacji społecznej.

Dlatego też nie mnożę w prezentowanym tekście egzemplifikacji, nie o to bowiem w nim chodzi. Korzystam $z$ ograniczonej bazy źródłowej, nie dokonując głębokiej kwerendy niepublikowanych w źródłach rękopiśmiennych (dzieła pisarzy starożytnych, średniowieczne kroniki) i ikonograficznych. Sądzę, że zestawienie pełnego katalogu odnośnych cytatów, aczkolwiek warte odrębnego obszernego opracowania monograficznego, w tym wypadku nie jest konieczne. Zebrany materiał w zupełności wystarcza do przedstawienia i uzasadnienia mojego głównego założenia. Chciałbym równocześnie zaznaczyć, że we wszystkich znanych źródłach w zasadzie cały czas powtarzana jest ta sama argumentacja co do zasadności i słuszności odbywania tego typu pojedynków (o tym niżej). Najważniejsza jest konstatacja, że takie wezwania spotyka się dość często zarówno w historii, jak i literaturze antycznej i średniowiecznej ${ }^{7}$.

7 Kolejne przykłady podaje V.M. Udwin, Between Two Armies: The Place of the Duel in Epic Culture, Leiden 1999. Autor ten, wyliczajac chronologicznie kolejne starożytne i średniowieczne egzemplifikacje, nie odróżnia niestety duellum 
Pojedynkom władców (principes) jako odrębnemu zagadnieniu nie poświęcono dotychczas w historiografii nowożytnej zbyt wiele uwagi. Wzmianki o nich znajdują się w różnego rodzaju opracowaniach ( $z$ zakresu historii wojen, biografiach), nikt jednak nie podjał się wyodrębnienia tego zjawiska i jego całościowego przebadania. Co więcej, historycy, którzy w jakiś sposób do niego nawiązywali, nie potrafili go docenić i błędnie je interpretowali. Stało się tak dlatego, że spoglądali na nie tylko jako na pewne niezbyt znaczace fakty $z$ przeszłości (element bitwy czy też biografii bohatera), bez ich społecznego i komunikologicznego kontekstu i niewarte bliższego zainteresowania. Należy jednak zrozumieć, że wezwania do walki osobistej królów nie mogą być dla historyka zaledwie zwykła ciekawostka bez większej wartości. Wrócę do tego w dalszej części tekstu.

Możliwość rozstrzygania losów wojny przez starcie dwóch zapaśników, reprezentujących obie strony konfliktu, znana była już w starożytności. Jednym $z$ najlepiej znanych motywów biblijnych jest walka Dawida $z$ Goliatem, który rzucił Izraelitom wyzwanie tymi słowy: „Jeżeli potrafi walczyć ze mna i położy mnie trupem, będziemy waszymi niewolnikami; ale jeżeli ja go przemogę i położe go trupem, wy będziecie naszymi niewolnikami i będziecie nam służyć" (1 Sm 17, 9).

Podobny watek spotykamy u Tytusa Liwiusza w opowieści o pojedynku Horacjuszy z Kuriacjuszami: „Przed rozpoczęciem boju przymierze zostało zawarte między Rzymianami a Albańczykami na takich warunkach, że bez dalszej walki ten naród będzie panował nad drugim, którego przedstawiciele odniosą zwycięstwo w tym pojedynku"9.

od ordalium, pojedynku wojowników od starcia królów, nie udało mu się także odszukać właściwego kontekstu tej problematyki. $Z$ tych też względów wartość jego opracowania odnośnie do zrozumienia interesującej nas problematyki, choć jest ono najpełniejsze i najbliższe założeniom mojego artykułu i skądinąd bardzo ciekawe, nie wykracza zbyt daleko poza zestawienie katalogowe. Por. także zestawienie przygotowane przez W. Goeza, Über Fürstenzwiekämpf im Spätmittelalter, „Archiv für Kulturgeschichte” 1967, Bd. XLIX, s. 135-163.

${ }_{8} \mathrm{Na}$ ten sam problem w odniesieniu do jednego źródła, dzieła Liutpranda $z$ Cremony, zwraca uwage także A.T. G rabow ski, The „duel” between Henry I and Arnulf of Bavaria according to Liudprand of Cremona [w:] Konfliktbewältigung und Friedensstiftung im Mittelalter, wyd. R. Czaja, E. Mühle, A. Radzimiński, Toruń 2012, s. 389. Na temat pojedynków jako metody rozwiązywania konfliktów por. także A.M. Auer, Vorgeschlagen, vereinbart, verhindert - Gottesurteile als mittel der konfliktlösung w tym samym tomie, szczególnie s. 181-185.

${ }^{9}$ Tytus Liwiusz, Dzieje od założenia miasta Rzymu: wybór, przekł. i oprac. W. Strzelecki, Wrocław 2004, s. 42. 
Ta sama praktyka znana była także w starożytnej Grecji. Jak dowiadujemy się $z$ Homerowego eposu, walczace w wojnie trojańskiej strony zgodziły się, by spór rozstrzygnięty został przez pojedynek Parysa $z$ Menelausem. Jak propozycję tę przedstawił Hektor:

Powiem, czego chce Parys, co te wzniecił boje:

Niechaj wojsko broń złoży i na ziemi siędzie,

A on sam $z$ Menelajem potykać się będzie:

Tak się i o dostatki, i o żonę rozprawi.

Kto kogo pojedynkiem na placu zostawi,

Ten Helenę i zbiory do domu zabierze,

My zaś na wieki trwałe uczynim przymierze (III, 90-96) ${ }^{10}$.

Żaden $z$ tych zapaśników nie był wodzem naczelnym armii czy władca państwa, jednak i pojedynki królów nie były wówczas niczym niezwykłym, by wymienić choćby przykład starcia Pyrrusa z Pantauchosem czy wyzwanie rzucone Cezarowi przez Antoniusza ${ }^{11}$. Kilka wieków później rzymski pisarz i historyk Wegecjusz (druga połowa IV w. n.e.), autor słynnego podręcznika wojskowości, wyrażał przekonanie, że dobrzy wodzowie, jeśli już muszą się narażać w bitwie, powinni to czynić po poważnym namyśle ${ }^{12}$. Możemy przypuszczać, $\dot{z}$ e nie był to jedynie jego prywatny sąd, lecz że przekazywał on $\mathrm{w}$ ten sposób opinio communis swych czasów. Wystarczy podkreślić wyrażoną w powyższych cytatach ideę pojedynku dwu wojowników, który ma rozstrzygnać losy całych plemion czy narodów.

Pojedynek mógł zastępować bitwę także we wczesnym średniowieczu, lecz nadal był to pojedynek dwóch wojowników niższej rangi (np. w czasie wojny Alemanów z Wandalami w Hiszpanii). Co istotne, w tym okresie „zaczęto uzasadniać zastępowanie bitwy w polu poprzez pojedynek tym, iż w ten sposób zaoszczędza się rozlewu krwi. Już w przypadku Teodoryka, króla $z$ rodu Merowingów, pod Quierzy nad Oisą, mówią wojownicy: "Lepiej, iżby padł jeden, niźli całe wojsko". Gdy w późnym średniowieczu wspomina się olśniewający i uroczyście ze wszelkimi szczegółami przygotowywany

${ }^{10}$ Homer, Iliada, przekł. F.K. Dmochowski, wstęp T. Sinko, Wrocław 2004, s. 52. Por. też. M. O s s ow s ka, Ethos rycerski i jego odmiany, Warszawa 1986, s. 27.

${ }^{11} \mathrm{Plu}$ tarch $z$ Cheronei, Żywoty sławnych mężów (z żywotów równoległych), przekł. i oprac. M. Brożek, t. I, Wrocław 2004, s. 355; ibidem, t. III, Wrocław 2006, s. 492, 503.

${ }^{12}$ Flawiusz Wegecjusz Renatus, Zarys wojskowości ksiag cztery, wyd. A.M. Komornicka, „Meander” 1974, R. XXIX, nr 4-5, s. 229-230. 
pojedynek, w którym dwaj królowie czy książęta wyrównać mieli swą querelle, na pierwszy plan wysuwa się wyraźnie motyw: pour éviter effusion de sang chrestien et la destruction du peuple"13. Duellum stało się jednym ze sposobów, w jaki chrześcijańskie średniowiecze, przez theatrum władzy, próbowało humanizować wojnę i ograniczać rozlew krwi, sięgając w tym celu po wzory antyczne (podobnej tezy dowodzi w swojej książce Victor Morris Udwin). Jak jednak widzimy, refleksja tego typu i podobne rozwiazania znane były dość szeroko także w świecie pogańskim.

Z założenia, że ksiazżę i wódz ponoszą odpowiedzialność za swój lud i wojsko, za ich dobrostan, zrodziła się idea, iż konflikt zbrojny rozstrzygany być powinien przez pojedynek wodzów obserwowany przez obie armie. Koncepcja taka rozpowszechniona była w wielu regionach Europy. Jak pisze francuski historyk P. Contamine: „Często w miejsce dwóch armii dwaj wodzowie wiodący spór lub wyznaczeni przez nich wojownicy sami wsteppowali w szranki. Owa praktyka, również zaświadczona przez Grzegorza $z$ Tours ${ }^{14}$, nie była zresztą ograniczona do świata germańskiego. W roku 971 planowano pojedynek między cesarzem bizantyjskim, Janem Tzimiskesem a ruskim księciem Światosławem; miał on rozstrzygnać spór między nimi, by uniknać masakry ich ludów. O podobnych planach, co prawda niemal zawsze porzucanych, zanim doszło do ich realizacji, mamy świadectwa w dziejach Zachodu aż po koniec średniowiecza" ${ }^{15}$.

Znajomość takiego obyczaju poświadczona jest również dla świata słowiańskiego. Według Kroniki węgierskiej z XIV w. w czasie panowania Mieszka II między Polakami a Pomorzanami wybuchła wojna, której powodem była odmowa płacenia przez Pomorzan Polsce trybutu. Jednakże kiedy wojska stanęły naprzeciwko siebie, obie strony uzgodniły, że lepszym rozwiązaniem będzie rozstrzygnięcie sporu przez pojedynek. Okazało się wówczas, że problemem jest wyznaczenie zawodników do owego starcia, gdyż zarówno Mieszko II, jak i jego

${ }^{13} \mathrm{~J} . \mathrm{Hu}$ izing a, Homo ludens: zabawa jako źródło kultury, Warszawa 1985, s. 135.

${ }^{14}$ „A gdy uzbrojeni wyszli do walki i już byli przygotowani do bitwy, rzekł król Alemanów: "Jak długo ma ta wojna doświadczać cały ten lud? Proszę, niech daremnie nie gina nasi i obcy ludzie, lecz niech dwaj z naszych wystapia do walki w zbroi wojennej i niech walczą między sobą. Wtedy ten, którego wojownik zwycięży, otrzyma krainę bez walki". Na to wszystek lud się zgodził, aby cała ta rzesza wojowników nie padła od miecza". Grzegorz z Tours, Historie: historia Franków, przekł. K. Liman, T. Richter; wstęp, oprac., komentarz D.A. Sikorski, Kraków 2002, s. 95-96.

${ }^{15}$ P. Contamine, Wojna $w$ średniowieczu, Warszawa 1999, s. 269-270. 
synowie wzdragali się przed walką. Honor polskiej strony uratować miał węgierski książę Bela, który oświadczył, „że choć się uważa za szlachetniejszego od owego poganina, to jednak będzie się bił na pożytek królestwa polskiego i cześć jego księcia. W starciu Bela zrzucił lanca Pomorzanina $z$ konia i przebił go mieczem. Wówczas książę Pomorzan uznał się za pokonanego i zgodził się na opłacenie trybutu. Odwdzięczając się wzajemnie książę Polaków oddał Beli swą córkę za żonę.

Historyjkę tę w nie zmienionej postaci przejął również do swoich Roczników Jan Długosz, skąd przeszła do popularnych ksiażek i podręczników"16. Zwróćmy uwagę, że ostatecznie nie doszło do pojedynku dwu władców, zamiast nich walczyli ze soba dwaj „rycerze”. O ile propozycja starcia książąt zapewne padła, na co wskazuje stwierdzenie, że Mieszko walczyć nie chciał, to była tylko jedną $z$ opcji do wyboru - do walki nie chcieli stanać także jego synowie. Wobec tego wydaje się, że myślą przewodnią tej kompromisowej propozycji była walka wręcz „znamienitych rycerzy” $z$ obu stron, choć niekoniecznie musieli być nimi wodzowie.

W następnym wieku „według legendy herbu Hełm godło to otrzymał mastalerz Bolesława Krzywoustego w 1111 r. w nagrodę za pokonanie w pojedynku wodza Prusów"17. Jak wskazuja oba przekazy, książę mógł wyznaczyć swego zastępcę, który stawał do pojedynku zamiast niego. W cytowanym wypadku rycerz walczył $z$ wodzem pogan. Niewatpliwie nie byłoby jednak możliwe, żeby król wyznaczył w swym zastępstwie rycerza, który walczyłby $z$ innym królem chrześcijańskim. W przypadku władców chrześcijańskich stający w szranki konkurenci musieli być sobie równi stanem.

Dalej na północny zachód Wilhelm Zdobywca „unika również, $z$ innych przyczyn, owych pojedynków między wodzami - poprzedzanych wysyłaniem wspaniale odzianych posłów, którzy przekazują wezwanie potrząsając laska i prawa rękawica swego pana - jakie praktykują niektórzy władcy i które stanowią wdzięczny temat dla epiki rycerskiej" ${ }^{18}$. Na pojedynek wyzwał Wilhelma

${ }^{16}$ G. Labuda, Mieszko II król Polski (1025-1034): czasy przełomu $w$ dziejach państwa polskiego, Kraków 1992, s. 175-176; J. Szymczak, op. cit., s. 76; J. Dłu gos z, Jana Długosza Roczniki czyli Kroniki sławnego Królestwa Polskiego, ks. 1 i 2 (do 1038), Warszawa 2009, s. 383.

17 K. Niesiecki, Herbarz polski, t. IV, Lipsk 1839, s. 345; J. Szymczak, op. cit., s. 23.

${ }^{18}$ P. Zu m th or, Wilhelm Zdobywca, Warszawa 1994, s. 147. 
przez swojego posła Conan II, książę Bretanii. Książę Normandii wyzwania nie przyją $1^{19}$.

Napotykamy tutaj na jedyna chyba wzmiankę na temat ceremoniału towarzyszącego wyzwaniu władcy na pojedynek przez innego władcę. Jako że właściwie nic o takim obrządku nie wiadomo, być może nie został on w ogóle opracowany, a do rzucenia wyzwania wystarczała zwykła praktyka. Biorac pod uwage to, jak rozbudowany był w dojrzałym i późnym średniowieczu ceremoniał rycerski w jego różnorakich aspektach, a także opisywane przez Johana Huizinge przygotowania do odbycia pojedynku (por. niżej), może to wskazywać, że istotnie traktowano te propozycje wyłącznie jako akt komunikacyjny, którego jedynym celem było przedstawienie symboliczne. Jego praktyczna realizacja nie miała większego znaczenia (działaniem władzy jest już sama jej dramaturgia), a wyzwania dokonywano w rutynowy sposób.

Warto zwrócić uwage na przemianę dokonująca się w wizerunku władcy w ciagu kolejnych stuleci. Choć „dzielna postawa na polu bitwy, odwaga osobista” sa cechami, które w późnym średniowieczu nadal odgrywaja zasadniczą rolę, to jednak zachodza w tej mierze interesujące zmiany. „We wczesnym i rozwiniętym średniowieczu monarcha dawał przykład swa postawa na wojnie nie tylko jako wódz, ale jako uczestniczący w walce wojownik. Co więcej, znane sa przypadki przesadnej wręcz brawury. Austriacka Kronika Rymowana Ottokara Styryjskiego podaje, iż w bitwie przeciw Rudolfowi Habsburgowi Przemysł Ottokar II chciał w pojedynkę zaatakować szyki nieprzyjacielskie i dopiero otoczenie powstrzymało go tłumacząc niewłaściwość takiego postępowania".

Jak pisze dalej Wojciech Iwańczak: „cechą charakterystyczną wizerunków króla w literaturze europejskiej jest to, iż władca coraz rzadziej osobiście uczestniczy w bitwie. O ile poczatkowo spotykamy opisy niezwykłych dokonań monarchów, którzy w pojedynkę mieli rozstrzygać o losach wojen i własna ręka kłaść pokotem tłumy nieprzyjaciół, to $z$ czasem w rozwiniętym i późnym średniowieczu $z$ pierwszej linii przesuwają się oni do tyłu i koncentrują swa uwage na dowodzeniu wojskiem" ${ }^{20}$. Świadczyłoby to o tym, że po okresie barbarzyńskiej nieodpowiedzialności nastąpił powrót do rozważnych rad Wegecjusza. W sprzeczności $z$ tym stoi jednak to,

${ }^{19}$ Ibidem, s. 213.

${ }^{20} \mathrm{~W}$. Iw ańczak, Tropem rycerskiej przygody: wzorzec rycerski $w$ piśmiennictwie czeskim XIV wieku, Warszawa 1985, s. 75-76. 
że jeszcze w czasie wojny stuletniej władcy uczestniczyli w walce osobiście, dowodząc nią i nie pozostając w ariergardzie. Przykłady można mnożyć: Filip VI pod Crécy w 1346 r.; w dziesięć lat później Jan II Dobry pod Poitiers dostał się do niewoli, a w $1441 \mathrm{r}$. Karol VII osobiście poprowadził szturm Pontoise. Po stronie angielskiej natomiast „Edward III i Henryk V stanowia wspaniałe przykłady monarchów demonstrujacych osobistą odwagę i talenty dowódcze"21. Ustalenie to jest dla mnie szczególnie istotne, gdyż tylko w atmosferze kultu osobistej dzielności rycerskiej władcy można mówić o jego uczestnictwie w pojedynkach.

Pojedynek bowiem był szczególną formą jej demonstrowania. Warto zaznaczyć, że w świadomości ludzi średniowiecza wojna rozumiana jako konflikt zbrojny dwu krajów nie była niczym więcej niż rodzajem rozszerzonego pojedynku, a bitwa różniła się od niego jedynie liczebnością walczących. Wobec takiej koncepcji, jednej $z$ wielu istniejacych, nic bardziej naturalnego niż ograniczenie skali i sprowadzenie bitwy tysięcy czy setek wojowników do duellum jeden na jeden.

Kilka akapitów swojej książki poświęcił pojedynkom władców Wojciech Iwańczak: „Na terenie Czech i Moraw spotkamy się z nim już w pochodzacym najprawdopodobniej z X w. Żywocie św. Wacława tzw. Krystiana. Książę Wacław zwycięża tam swego - również książęcego - przeciwnika. Epizod ten włączony został także do późniejszych opracowań Żywota św. Wacława. Znajdujemy go na przykład w wersji zredagowanej przez Karola IV. Gdy oba wojska stanęły naprzeciw siebie, Wacław zaproponował, by dla oszczędzenia krwi wojowników obaj książęta zmierzyli się ze sobą, a wynik ich pojedynku wyznaczy zarazem zwycięska stronę w bitwie. Interwencja niebios na rzecz św. Wacława nie dopuściła jednak do stoczenia walki.

W późniejszych czasach sytuacje tego typu, znane również ze źródeł zachodnioeuropejskich - na przykład planowany a nie zrealizowany pojedynek Ryszarda II z Karolem VI w 1386 r. - nie ominęły także najbogatszego w doświadczenia rycerskie $z$ władców czeskich Jana Luksemburskiego. W 1332 r. książę Jan Brabancki proponuje $\mathrm{mu}$ - przez herolda $z$ nagim mieczem w dłoni - dzień oraz określone miejsce walki. Król jednak kazał mu przez całe trzy dni czekać na deszczu.

${ }^{21}$ C. All a man d, Wojna stuletnia: konflikt i społeczeństwo, Kraków 2012, s. 96. 
Innym razem w czasie zmagań Jana Luksemburskiego $z$ Kazimierzem Wielkim pod Krakowem, projekt pojedynku władców przybrał jeszcze bardziej oryginalną formę. Powód propozycji złożonej przez Kazimierza Wielkiego spotkaliśmy już choćby w Żywocie św. Wacława. Pojedynek władców zdecydowałby o zwycięstwie jednej ze stron i zaoszczędził wiele istnień ludzkich. [...] W ostatnim przypadku do skrzyżowania broni nie dochodzi, gdyż ślepy już wówczas Jan Luksemburski dla wyrównania szans w pojedynku proponuje Kazimierzowi wyłupienie sobie oczu, na co ten zgodnie $z$ naszymi oczekiwaniami nie jest skłonny przystać.

Odmienność perspektywy literackiej i rzeczywistej znajduje potwierdzenie $\mathrm{w}$ tym, iż $\mathrm{w}$ literaturze operującej materiałem bohaterów antycznych do wymarzonego pojedynku władców jednak dochodzi. W staroczeskiej opowieści prozą o Aleksandrze Wielkim, opracowaniu łacińskiej Historia de proeliis pochodzacej $z$ drugiej połowy XIV w., znajdujemy dwa takie przypadki, przy czym w obu Aleksander zwycięża swych przeciwników, także monarchów"22.

Wstęp do książki Marca Blocha o królach cudotwórcach rozpoczyna się opisem, jak „27 kwietnia 1340 r. brat Franciszek $z$ zakonu dominikanów, biskup Bisaccii w prowincji neapolitańskiej, kapelan króla Roberta Andegaweńskiego i w owej chwili poseł króla Anglii Edwarda III, staną przed dożą weneckim. Między Francja a Anglia rozgorzał właśnie spór dynastyczny, który miał się przekształcić w Wojnę Stuletnią. [...] Brat Franciszek otrzymał od swego zwierzchnika zdanie, by uzyskać poparcie Wenecjan i za ich pośrednictwem zabiegać o przyjaźn Genueńczyków. Zachował się skrót jego przemowy. Jak przystało, chwalił on pokojowe zamiary króla angielskiego. "Najjaśniejszy książę Edward", pragnąc gorąco uniknąc masakry wielu niewinnych chrześcijan, napisał - jeśli wierzyć bratu Franciszkowi - do "Filipa Walezjusza, mieniącego się królem Francji«, aby ten spośród trzech propozycji stoczenia wielkiego boju wybrał, bez wojny, jedną: albo zatem bój w formie pojedynku między dwoma królami - prawdziwy sąd boży - albo też walka dwóch grup liczących od sześciu do ośmiu wiernych"; albo też jedna $z$ dwu innych prób. Filip miał odrzucić wszystkie te propozycje. Jednak „można wątpić, czy Edward III rzeczywiście propozycje takie kiedykolwiek wysuwał. [...] próby lwów i cudu nie należałoby brać na serio, podobnie jak i zaproszenia do pojedynku - klasycznej

${ }^{22}$ W. Iwańczak, Tropem rycerskiej przygody..., s. 78-80. 
w owym czasie zaczepki rozpoczynających wojnę władców. Ci wiedzieli przecież jak zachować życie i nigdy, jak sięgnąć pamięcią, nie widziano, by stawali w szranki bojowe. Mamy tu więc do czynienia ze zwykłymi formułkami dyplomatycznymi lub - jak w tym konkretnym przypadku $-z$ rzucanymi na wiatr słowami nazbyt gadatliwego dyplomaty"23.

Kolejne przykłady, które można wymienić, pochodza $z$ roku 1283, kiedy „królowie Neapolu i Sycylii, Karol Andegaweński i Piotr Aragoński byli gotowi w pojedynku rozstrzygnąć różnice polityczne" ${ }^{24}$, oraz z 1346 r., gdy - jak pisze Wojciech Iwańczak - Filip VI proponował Edwardowi III rozstrzygnięcie losów wojny przez pojedynek władców. „Król Anglii przyjął wyzwanie, ale, dodając szyderczy komentarz, że uczyni to dopiero wtedy, gdy jego wojska dotra pod Paryż"25.

Według relacji Jana Długosza w 1470 r. inny czeski władca, Jerzy z Podiebradu, wyzwał króla Węgier Macieja Korwina na pojedynek, którego wynik miałby rozstrzygnąć toczoną wojnę. Maciej jednak wyzwania nie przyją ${ }^{26}$.

Wciąż wierny średniowiecznym ideałom rycerskim cesarz Karol V, ostatni cesarz średniowieczny, rozważał pytanie, po co posyłać żołnierzy, aby zabijali się $z$ powodu rywalizacji władców? To oni sami powinni bezpośrednio i osobiście rozstrzygną́ między sobą sporne kwestie. Pozostajac wierny swoim przekonaniom, wyzwał zatem Franciszka I na pojedynek. „Wcześniej jeszcze - gdy francuski monarcha nie wypełniał postanowień traktatu madryckiego - wezwał posła francuskiego i powiedział mu, że uważa jego króla za człowieka podłego i nikczemnego". To samo oskarżenie znalazło się później w liście Karola do posła z 18 marca 1528 r.: „Król, wasz pan postapił podle i nikczemnie, nie dotrzymujacc słowa, jakie mi dał, aby zawrzeć ugodę w Madrycie, a jeśli zechciałby temu zaprzeczyć, podtrzymam to osobiście wobec jego osoby".

${ }^{23}$ M. Bloch, Królowie Cudotwórcy: studium na temat nadprzyrodzonego charakteru przypisywanego władzy królewskiej zwłaszcza we Francji i Anglii, Warszawa 1998, s. 49-50.

${ }^{24}$ E.H. Kantorowicz, op. cit., s. 209.

${ }^{25}$ W. Iwańczak, Jan Luksemburski: dzieje burzliwego żywota i bohaterskiej śmierci króla Czech i hrabiego Luksemburga w 21 odsłonach, Warszawa 2012, s. 288.

${ }^{26}$ J. Długosz, Roczniki czyli Kroniki sławnego Królestwa Polskiego, ks. 12 (1462-1480), Warszawa 2009, s. 267; Rozbiór krytyczny Annalium Poloniae Jana Długosza z lat 1445-1480, t. II, Wrocław-Warszawa-Kraków 1965, s. 266-267; J. Szymczak, op. cit., s. 78. 
Franciszek wyzwanie przyjął. „I chociaż uczynił to w sposób niezbyt właściwy dla rycerskiego obyczaju - nie zapominajmy, że Karol V był rycerzem Zakonu Złotego Runa - cesarz zaakceptował odpowiedź "ze względu na moje pragnienie, aby własną osobą dochodzić spraw spornych, unikając większego rozlewu krwi». O wszystkim powiadomił publicznie dwór, proszac, aby mu doradzono, co najbardziej przystoi jego czci.

Jako miejsce pojedynku Karol wyznaczył granicę francuska pomiędzy Fuenterrabía i Hendayą, określając termin czterdziestu dni. Kiedy jednak cesarski herold stawił się na francuskim dworze, Franciszek I gwałtownie mu przerwał, nim ten zdołał przedstawić propozycję Karola V. Tak więc pojedynek się nie odbył"27.

I wreszcie ostatni dłuższy cytat, pochodzaccy z dzieła wielkiego historyka holenderskiego, który warto przytoczyć w całości: „Szczególna formą fikcji rycerskiej służącą reklamie politycznej był stale zapowiadany i nigdy nie urzeczywistniany pojedynek książąt. [...] zatargi między państwami były w XV stuleciu ujmowane jeszcze jako walki stronnictw, jako osobista querelle. [...] Cóż mogło być bardziej naturalne niż to, że władcy osobiście się potykają; o takich potyczkach marzy się jeszcze dziś podczas politycznych pogawędek $\mathrm{w}$ pociagu. $\mathrm{W}$ istocie takie rozwiazanie, które zadowalało zarówno prymitywne poczucie prawa, jak i rycerska fantazję, stawało nieustannie na porzackku dziennym. Gdy czytamy o skrupulatnych przygotowaniach do książęcych pojedynków, rodzi się w nas wówczas wątpliwość, czy to wszystko było tylko piękną igraszka świadomej obłudy - a więc znowu przejawem pogoni za pięknym życiem - czy też może książęcy zapaśnicy rzeczywiście oczekiwali walki. Widać wyraźnie, że dziejopisarze owej epoki pojmowali rzecz równie poważnie, jak i sami, żądni walki, władcy. W Bordeaux, w r. 1283, wszystko było już przygotowane do pojedynku między Karolem Andegaweńskim i Piotrem Aragońskim. W roku 1383 Ryszard II poleca swemu wujowi, Janowi Lancastrowi, aby prowadził rokowania pokojowe $z$ królem francuskim; jako właściwa do tego drogę Jan ma zaproponować pojedynek, do którego stanęliby obaj królowie; Ryszard mógłby też stanać wraz z trzema swymi stryjami, a Karol ze swymi krewnymi. Monstrelet od razu na początku swej kroniki poświęca wiele miejsca wyzwaniu króla angielskiego, Henryka IV, przez Ludwika Orleańskiego. Humphreya z Gloucester

${ }^{27}$ M.F. Álvarez, Cesarz Karol V, Warszawa 2003, s. 113-114. 
wyzwał w roku 1425 na pojedynek Filip Dobry; Filip był zreszta człowiekiem najbardziej właściwym do ozdobienia tego pysznego tematu przy pomocy wszystkich środków swego bogactwa i przez swe umiłowanie okazałości. W wyzwaniu wymienia się wyraźnie motyw: "aby zapobiec rozlaniu krwi chrześcijańskiej i wyniszczeniu ludu, któremu moje serce okazuje współczucie", "żeby ten spór został doprowadzony do końca przeze mnie osobiście, bez kroczenia droga wojny, na skutek której wielu ze szlachty, zarówno $z$ waszego, jak i mojego wojska, musiałoby zakończyć swoje dni w żałosny sposób“. Wszystko zostało przygotowane do walki: gotowy był kosztowny ekwipunek i wspaniałe stroje, które miał nosić książę, pracowano przy namiotach, sztandarach i choragwiach, przy zbrojach dla heroldów i dla poursuivants, przybrano wszystko herbami krajów książęcych - krzemieniem i krzyżem św. Andrzeja. Filip oddawał się treningowi: "zarówno przez wstrzemięźliwość w pokarmie, jak i przez przykładanie się do ćwiczeń". W swym parku, w Hesdin, wprawiał się co dzień pod kierunkiem doświadczonych nauczycieli szermierki. Rachunki informują nas o kosztach, jakie to wszystko pociagnęło. Jeszcze w roku 1460 można było oglądać w Lille drogocenny namiot, przygotowany specjalnie w tym celu. Ale $z$ pojedynku nic nie wyszło.

To nie przeszkadzało Filipowi wyzwać później do walki księcia saskiego w sporze o Luksemburg; na uroczystości zaś w Lille, gdy Filip miał prawie sześćdziesiąt lat, jego ślub jako krzyżowca brzmiał: $z$ chęcia jest gotów walczyć twarzą w twarz $z$ Wielkim Turkiem, gdyby ten sobie tego życzył. [...]

Motyw ten utrzymywał się jeszcze we Włoszech w epoce rozkwitu Odrodzenia. Francesco Gonzaga wyzywa na pojedynek Cezara Borgię; mieczem i sztyletem chce on uwolnić Włochy od strasznego i znienawidzonego wroga. Pośrednictwo króla francuskiego, Ludwika XII, udaremnia pojedynek i wydarzenie kończy się wzruszajacym pojednaniem. Jeszcze Karol V dwukrotnie w różnych formach ofiarowywał się załagodzić spór z Franciszkiem I za pośrednictwem osobistego pojedynku; po raz pierwszy, gdy Franciszek I po powrocie $z$ niewoli wojennej, zdaniem cesarza, złamał swoje słowo, i na nowo w roku 1536. Godnie zamyka ten szereg wyzwanie, które Karol Ludwik $z$ Palatynatu skierował w roku 1674, wprawdzie nie osobiście do Ludwika XIV, lecz do Turenne'a"28.

${ }^{28}$ J. Huizinga, Jesień średniowiecza, Warszawa 1992, s. 123-125. 
Oczywiście realnie do żadnego pojedynku władców nigdy nie doszło. Ale nie $z$ „tchórzostwa”, przecież królowie często stawali do walki w bitwach $z$ bronia w ręku. Choć więc „kronikarze skrzętnie odnotowywali wyzwania rzucane sobie przez władców i ze szczegółami opisywali długie przygotowania do pojedynków trudno przypuszczać, by naprawdę oczekiwali od swych monarchów wstąpienia w szranki. Liczył się bowiem sam fakt wyzwania, przez który demonstrowano i podkreślano rycerskie cnoty dynasty. Koniec XIV i pierwsza połowa XV w. to w Europie Zachodniej czas nieustannych przygotowań do pojedynku władców. Tylko nieliczni $z$ nich nigdy nie rzucili ani nie otrzymali wyzwania do walki" ${ }^{29}$. Wezwanie wrogiego księcia do pojedynku było rytualnym aktem komunikacyjnym, którego celem było ideowe podkreślenie własnej racji, przekonania o tym, że broni się słusznej sprawy, że ma się po swojej stronie Boga, a także okazanie, że władca dba o swój lud, swoje wojsko i że jest gotów ich bronić. Jednak jako akt rytualny nie musiało to za soba pociagać konieczności realnego, fizycznego działania. Tego chyba nie rozumieli cytowani tu historycy natykający się w swoich badaniach na problem pojedynków książąt i którzy wyrażali swoje zdziwienie czy ironię w stosunku do tych gestów rytualnych, lekceważąco sytuujac je w sferze fikcji. Trzeba zrozumieć, że miały one swoje bardzo konkretne znaczenie. Wyzwanie rzucone przez Kazimierza Wielkiego Janowi Luksemburskiemu, potraktowane przez warszawskiego uczonego jedynie jako anegdota, odgrywało bardzo konkretną rolę komunikacyjną. To, co tak plastycznie opisuje Huizinga, nie było tylko pustą formą bez treści; to jedynie historycy, którzy zwracali uwagę na ten problem, nie potrafili go właściwie opisać.

Władcy byli (i są nadal) aktorami, z których jeden usiłuje, $z$ zachowaniem formy rytualnej, narzucić swoją wolę drugiemu. Ten drugi zaś, wchodzac w swoja rolę, rytualnie przyjmuje wyzwanie, choć jest to gest, który łatwo mylnie uznać (szczególnie $z$ perspektywy zewnętrznego obserwatora, nierozumiejacego dynamiki zachodzących procesów) za faktycznie pusty. Badając tę problematykę, trzeba uzmysłowić sobie, że dramaturgia władzy jest jej działaniem.

Pojedynek wodzów rozstrzygających osobiście losy wojny jest motywem bardzo malowniczym, wnoszącym silny element napięcia emocjonalnego i stąd wykorzystywanym wielokrotnie w literaturze.

${ }^{29}$ D. Piwow a rczyk, Obyczaj rycerski w Polsce późnośredniowiecznej (XIV-XV wiek), Warszawa 1998, s. 171-172. 
Sięgnał po niego m.in. Miguel de Cervantes Saavedra w Numancji (nowela ta nie ma w sobie nic $z$ satyry Don Kichota). Iberyjscy mieszkańcy tytułowego grodu w czasie wojen punickich zostali oblężeni przez Rzymian. Obrońcy proponowali wrogom zrazu honorowa kapitulację, a gdy ta nie została przyjęta, rozstrzygnięcie losów wojny przez pojedynek, co również zostało odrzucone ${ }^{30}$. Podobny wątek pojawił się w pierwszej połowie XIII w. w Parsifalu Wolframa von Eschenbach, gdy król Klamide oblegajacy Pelrapeir po przegranej w pojedynku $z$ Parsifalem się wycofał ${ }^{31}$. We wcześniejszej o kilkadziesiąt lat Pieśni o Nibelungach (ok. 1200 r.) Zygfryd rzucił wyzwanie Guntherowi, aczkolwiek tu sytuacja była odmienna. Nie chodziło o rozstrzygnięcie pojedynkiem losów wojny, a „tylko" o rycerskie duellum, którego stawką miało być królestwo („Jeżeli jesteś tak odważny, aby stanąć ze mną do rycerskiego pojedynku, walcz ze mną o koronę i życie. Chętnie nazwałbym ten zamek moim własnym [...] wszystko, co mam stanie, się twoją własnością, jeśli mnie pokonasz. W przyszłości będzie cię słuchał cały kraj Nibelungów") ${ }^{32}$.

Wspomniany Jan Luksemburski uczestniczył w wyprawach krzyżowych przeciwko pogańskim Prusom i Litwinom. Przygody te uwiecznione zostały $\mathrm{w}$ dziełach literackich. W Myreur des histors kronikarz $z$ Liège Jean d'Outremeuse opowiadał o przygotowaniach do pojedynku króla czeskiego z przywódca „Saracenów” Margalisem pod murami obleganej twierdzy litewskiej. Ostatecznie jednak i do tego pojedynku nie doszło ${ }^{33}$.

Rzadziej natomiast starcia takie przedstawiane były w sztukach plastycznych. Jako przykład wskazać chciałbym dwie miniatury pochodzace ze średniowiecznych rękopisów. Pierwsza przedstawia pojedynek angielskiego króla Edmunda II Żelaznobokiego z duńskim Kanutem Wielkim. Scena ta rozegrać się miała w czasie bitwy pod Assandun (18 października 1016). Ilustracja pochodzi

${ }^{30}$ Najnowsze wydania: A. He r m e n e gild o, La destruición de Numancia, Madrid 1994, Clásicos Castalia, 207; G. Gilabert, Tragedia de Numancia, Nürnberg 2014. Por. też Z. Szm y d tow a, Cervantes, Warszawa 1965, s. 57.

${ }^{31}$ Wolfram von Eschenbach, Werke, hrsg. K. Lachmann, Berlin 1891, 185: 25-28.

${ }^{32}$ K. Treumund, Saga o Nibelungach, przekł. A. Sznaper, Gdańsk 2000, 18. Por. też V.M. Udwin, op. cit., passim.

${ }^{33}$ Le myreur des histors, chronique de Jean des Preis dit d'Outremeuse, publiée S. Bormans, t. VI, Bruxelles 1887, s. 414-415. Por. też W. Iwańczak, Jan Luksemburski..., s. 197. 
z kroniki Mateusza z Paryża (il. 1). Druga natomiast to wyimaginowany pojedynek Ryszarda Lwie Serce $z$ Saladynem (angielski rękopis $z$ ok. 1340 r., il. 2).

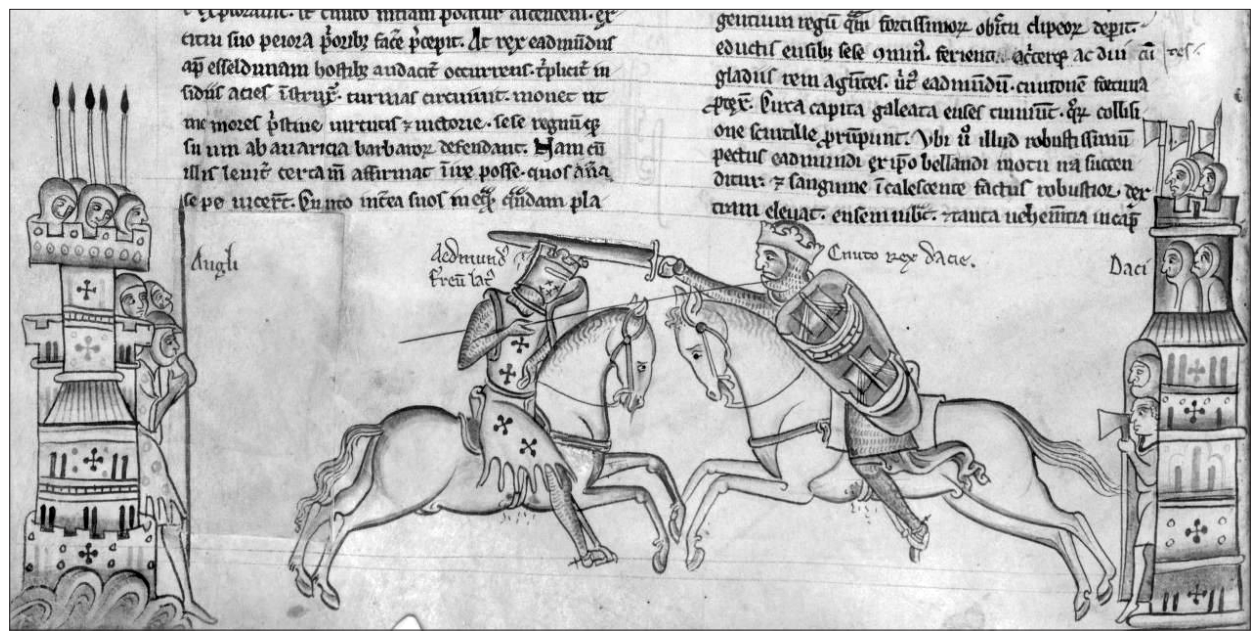

1. Pojedynek angielskiego króla Edmunda II Żelaznobokiego $z$ władca duńskim Kanutem Wielkim (Mateusz z Paryża, Historia Anglorum, XIII w., Wikimedia Commons)

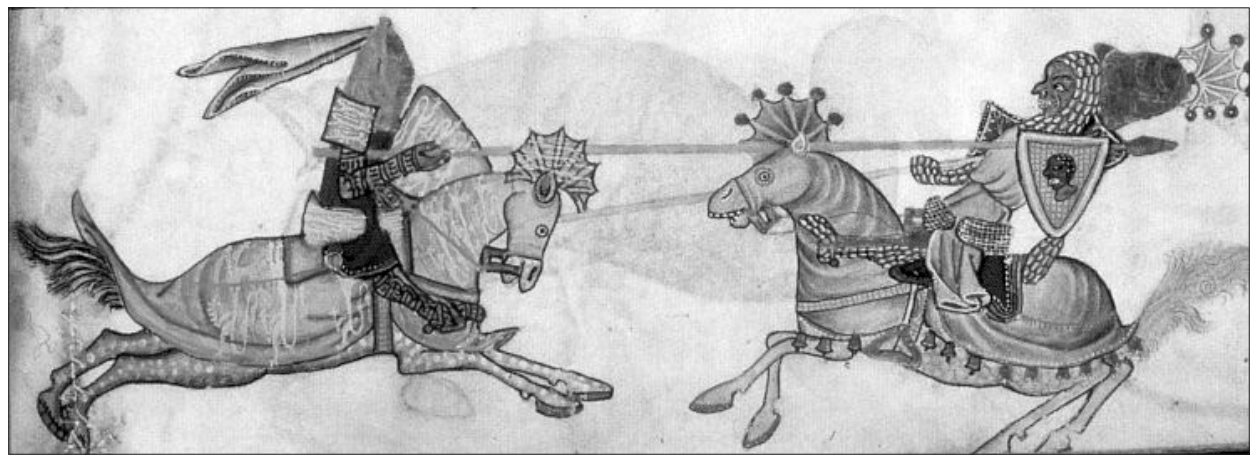

2. Wyimaginowany pojedynek Ryszarda Lwie Serce $z$ Saladynem (angielski rękopis $z$ ok. 1340 r., Wikimedia Commons)

Pojedynkujących się książąt zrodziło średniowiecze ze swym ethosem rycerskim i porządkiem feudalnym. Idea ta odeszła do przeszłości wraz z nimi. Motyw ten co prawda powracał jeszcze w czasach nowożytnych, ale już tylko jako jej echo i łabędzi śpiew. Maria Ossowska, która śledziła przemiany ethosu rycerskiego, stwierdza, że w czasach nowożytnych punkt ciężkości ideału przesuwał się 
od rycerskiego współzawodnictwa orężnego ku wzorcom dworskim. Dzisiejsze „pojedynki władców” prowadzi się co prawda w innych formach, choć nie mniej brutalnie.

Tekst ten przyjdzie zamknąc klamra. Ian Kershaw w książce Mit Hitlera: wizerunek a rzeczywistość w III Rzeszy (Zakrzewo 2009) wskazał na teologiczny wymiar władzy totalitarnej ${ }^{34}$. W Trzeciej Rzeszy Führer był ucieleśnieniem Idei, którą wielbiono za jego pośrednictwem, owego Mitu właśnie, w który ubrała go nazistowska propaganda. Mniej ważna była fizyczna osoba wodza. On też zatem miał dwa Ciała. Oczywiście pochodzenie i legitymizacja władz (królewskiej, opisanej przez E.H. Kantorowicza, oraz nazistowskiej) były różne, narzędzia ich sprawowania jednak - w pewnym sensie podobne. Jak czytamy we wstępie, „powodów jego [Hitlera - przyp. P.T.] olbrzymiej popularności należy szukać "nie tyle w samym wodzu, ile w tych, którzy go podziwiali"”. Wydaje mi się jednak, że punkt ciężkości leżał zarówno poza Wodzem, jak i poza ludźmi, którzy go podziwiali i akceptowali. Oni potrzebowali Idei, Mitu i uwierzyli, że Hitler jest jego ucieleśnieniem.

Czemu o tym wspominam? Otóż wydaje się niewątpliwe, że theatrum komunikacji rytualnej przetrwało niezmienione $\mathrm{w}$ swym rdzeniu do XX i XXI w. (czego dowodzi zreszta także ksiażka E.W. Rothenbuhlera). Symbolicznym zakończeniem wojny jest akt zgładzenia wrogiego przywódcy (to też zresztą motyw znany od starożytności, by przypomnieć choćby Judytę i Holofernesa), choć już nikt nie rzuca wyzwań na osobisty pojedynek. Ale temu celowi służyć miał zamach na Hitlera (czyli ściślej rzecz biorąc: na Mit ucieleśniany przez jego fizyczna osobę), a w ostatnich latach polowanie na Osamę bin Ladena, Saddama Husajna czy Muammara Kadafiego. I faktycznie, miał rację Johan Huizinga, gdyż do dziś pojedynki podobne średniowiecznym w polityce się odbywają, kiedy walczą ze soba przywódcy partii, rządzącej i opozycyjnej. Nie sa to już starcia na kopie i miecze, choć bywają równie brutalne jak tamte. W zmienionej, uwspółcześnionej (nie pierwszy zresztą raz) formie rytuał trwa. Wiadomo przecież, że wojna to nic innego niż polityka prowadzona innymi środkami.

${ }^{34}$ Do podobnych wniosków doszedł także Norman Cohn, W pogoni za milenium: milenarystyczni buntownicy i mistyczni anarchiści średniowiecza, Kraków 2007, s. 263-266. 


\section{Bibliografia}

\section{Ź RÓDEA DRUKOWANE}

Długosz J., Jana Długosza Roczniki czyli Kroniki sławnego Królestwa Polskiego, ks. 1 i 2 (do 1038), Warszawa 2009.

Długosz J., Roczniki czyli Kroniki sławnego Królestwa Polskiego, ks. 12 (1462-1480), Warszawa 2009.

Flawiusz Wegecjusz Renatus, Zarys wojskowości ksiag cztery, wyd. A.M. Komornicka, „Meander” 1974, R. XXIX, nr 4-5, s. 198-232.

Gilabert G., Tragedia de Numancia, Nürnberg 2014.

Grzegorz z Tours, Historie: historia Franków, przekł. K. Liman, T. Richter; wstęp, oprac., komentarz D.A. Sikorski, Kraków 2002.

Hermenegildo A., La destruición de Numancia, Madrid 1994, Clásicos Castalia, 207. Homer, Iliada, przekł. F.K. Dmochowski, wstęp T. Sinko, Wrocław 2004.

Le myreur des histors, chronique de Jean des Preis dit d'Outremeuse, publiée S. Bormans, t. VI, Bruxelles 1887.

Niesiecki K., Herbarz polski, t. IV, Lipsk 1839.

Plutarch z Cheronei, Żywoty sławnych mężów (z żywotów równoległych), przekł. i oprac. M. Brożek, t. I, Wrocław 2004; t. III, Wrocław 2006.

Treumund K., Saga o Nibelungach, przekł. A. Sznaper, Gdańsk 2000.

Tytus Liwiusz, Dzieje od założenia miasta Rzymu: wybór, przekł. i oprac. W. Strzelecki, Wrocław 2004.

Wolfram von Eschenbach, Werke, hrsg. K. Lachmann, Berlin 1891.

\section{Opracowania}

Allamand C., Wojna stuletnia: konflikt i społeczeństwo, Kraków 2012.

Althoff G., Potega rytuału: symbolika władzy w średniowieczu, Warszawa 2011.

Álvarez M.F., Cesarz Karol V, Warszawa 2003.

Auer A.M., Vorgeschlagen, vereinbart, verhindert - Gottesurteile als mittel der konfliktlösung, [w:] Konfliktbewältigung und Friedensstiftung im Mittelalter, wyd. R. Czaja, E. Mühle, A. Radzimiński, Toruń 2012, s. 181-196.

Bloch M., Królowie Cudotwórcy: studium na temat nadprzyrodzonego charakteru przypisywanego władzy królewskiej zwłaszcza we Francji i Anglii, Warszawa 1998.

Buc P., Pułapki rytuału: między wczesnośredniowiecznymi tekstami a teoria nauk społecznych, Warszawa 2011.

Cohn N., W pogoni za milenium: milenarystyczni buntownicy i mistyczni anarchiści średniowiecza, Kraków 2007.

Contamine P., Wojna $w$ średniowieczu, Warszawa 1999.

Goez W., Über Fürstenzwiekämpf im Spätmittelalter, „Archiv für Kulturgeschichte” 1967, Bd. XLIX, s. 135-163. 
Grabowski A.T., The „duel” between Henry I and Arnulf of Bavaria according to Liudprand of Cremona, [w:] Konfliktbewältigung und Friedensstiftung im Mittelalter, wyd. R. Czaja, E. Mühle, A. Radzimiński, Toruń 2012, s. 387-400.

Huizinga J., Homo ludens: zabawa jako źródło kultury, Warszawa 1985.

Huizinga J., Jesień średniowiecza, Warszawa 1992.

Iwańczak W., Jan Luksemburski: dzieje burzliwego żywota i bohaterskiej śmierci króla Czech i hrabiego Luksemburga w 21 odsłonach, Warszawa 2012.

Iwańczak W., Tropem rycerskiej przygody: wzorzec rycerski $w$ piśmiennictwie czeskim XIV wieku, Warszawa 1985.

Kantorowicz E.H., Dwa Ciała Króla: studium ze średniowiecznej teologii politycznej, Warszawa 2007.

Labuda G., Mieszko II król Polski (1025-1034): czasy przełomu w dziejach państwa polskiego, Kraków 1992.

Le Goff J., Święty Ludwik, Warszawa 2001.

Ossowska M., Ethos rycerski i jego odmiany, Warszawa 1986.

Piwowarczyk D., Obyczaj rycerski w Polsce późnośredniowiecznej (XIV-XV wiek), Warszawa 1998.

Rothenbuhler E.W., Komunikacja rytualna: od rozmowy codziennej do ceremonii medialnej, Kraków 2003.

Roux J.-P., Król: mity i symbole, Warszawa 1998.

Rozbiór krytyczny Annalium Poloniae Jana Dtugosza z lat 1445-1480, t. II, Wrocław-Warszawa-Kraków 1965.

Szmydtowa Z., Cervantes, Warszawa 1965.

Szymczak J., Pojedynki i harce, turnieje i gonitwy. Walki o życie, cześć, sławę i pieniadze w Polsce Piastów i Jagiellonów, Warszawa 2008.

Taylor C., Chivalry and the Ideals of Knighthood in France during the Hundred Years War, Cambridge 2013.

Trim D.J.B., The Chivalric Ethos and the Development of Military Professionalism, Leiden 2008.

Udwin V.M., Between Two Armies: The Place of the Duel in Epic Culture, Leiden 1999.

Zakrzewski L.S., Ethos rycerski $w$ dawnej i współczesnej wojnie, Warszawa 2004.

Zumthor P., Wilhelm Zdobywca, Warszawa 1994. 
Piotr TAfiŁowski

\section{Duels of the rulers: the question of ritual communication}

he paper seeks to explain the significance of the phenomenon, which were
the duels of monarchs. They appear to be best understood if analyzed in the
context of ritual communication. Challenges to monarchs to fight a duel, although
none actually took place, were widespread gestures from antiquity to the modern
times. They are known from many documented, literary (Iliad) and iconographic
sources and also from chronicles. It appears, however, that historians have not so
far devoted proper attention to them and failed to correctly interpret this problem
and explain it adequately. The present study is an attempt to look at the subject
from a new angle.

Keywords: duel, monarchs, ritual communication. 